\title{
ISPITIVANJE PERCEPCIJE I PRODUKCIJE GLAZBENOG RITMA KOD OSOBA S AFAZIJOM
}

\author{
PAOLA DANJEK ${ }^{1}$, TATJANA PRIZL JAKOVAC ${ }^{2}$ \\ ${ }^{1}$ Odjel za medicinsku rehabilitaciju djece, Specijalna bolnica za medicinsku rehabilitaciju Krapinske Toplice, \\ kontakt: paola.danjek@gmail.com, \\ ${ }^{2}$ Odsjek za logopediju, Edukacijsko-rehabilitacijski fakultet Sveučilišta u Zagrebu
}

Primljeno: 30.12 .2019 .

Izvorni znanstveni rad

Prihvaćeno: 30.04 .2020 .

UDK: $81 ` 234.2: 781.62$

doi: $10.31299 /$ hrri.56.1.2

Sažetak: Za razumijevanje i kreiranje logopedskih tretmana za osobe s neurogenim komunikacijskim, jezičnim i govornim poremećajima, poput onih namijenjenih osobamas afazijom netečnog tipa, potrebno je istraživati vezu između ritma i govora. Cilj opisanog istraživanja, u kojem je sudjelovalo 10 ispitanika s afazijom i 10 prosječnih govornika, bio je otkriti postoje li teškoće percepcije i produkcije glazbenog ritma kod osoba s afazijom, ispitati postoje li razlike između percepcije i produkcije glazbenog ritma kod iste skupine ispitanika te utvrditi postoji li povezanost izmedu postignuća na zadacima auditivnog razumijevanja riječi $i$ rečenica te sposobnosti percepcije i produkcije glazbenog ritma kod obiju skupina ispitanika. "Protokol za ispitivanje percepcije $i$ produkcije ritma kod osoba s afazijom", koji sadrži zadatke za percepciju i produkciju glazbenog ritma, kreiran je za potrebe ovog istraživanja. Statističkom analizom podataka utvrđena je statistički značajna razlika između sposobnosti percepcije i produkcije glazbenog ritma kod osoba s afazijom. Usto potvrđena je statistički značajna razlika između postignuća skupine osoba s afazijom i kontrolne skupine ispitanika. Ovim istraživanjem nije utvrđena statistički značajna povezanost između postignuća na zadacima auditivnog razumijevanja riječi i rečenica i sposobnosti percepcije i produkcije glazbenog ritma kod obiju skupina ispitanika. Analizom odgovora ispitanika otkrivene su značajke ritamskih obrazaca koje ispitanici najbolje, odnosno najlošije percipiraju $i$ reproduciraju.

Ključne riječi: afazija, ritam, percepcija, produkcija, glazbena terapija

\section{UVOD}

Poznato je da u mozgu postoje specijalizirana područja uključena u jezične i glazbene aktivnosti te da tijekom provođenja sličnih kognitivnih operacija u specijaliziranim područjima mozga sudjeluju neuralne veze zajedničke tim dvjema domenama (Patel, 2012). Na ovim premisama temelje se istraživanja povezanosti govora i glazbe. Dodatan argument za proučavanje veze govora i glazbe jest tvrdnja da je ritamska struktura temelj i govora i glazbe (Patel, 2008; prema Ding i sur., 2017) jer su organizirane ritmičke i melodijske strukture prisutne u dva oblika ljudske produkcije - u govornoj prozodiji i glazbi (Patel, Iversen i Rosenberg, 2006). Iz usporednog prikaza glazbenih sastavnica i prozodijskih obilježja govora vidljivo je da govor i glazba dijele brojna zajednička obilježja (Tablica 1).
Tablica 1. Glazbene sastavnice i prozodijska obilježja govora

\begin{tabular}{|l|l|}
\hline Glazbene sastavnice & Prozodijska obilježja govora \\
\hline ton & ton \\
\hline intonacija & govorna melodija \\
\hline dinamika & naglasci \\
\hline tempo & tempo / govorna brzina \\
\hline ritam & ritam \\
\hline stanke & stanke \\
\hline timbar & timbar \\
\hline harmonija & spektralni sastav \\
\hline
\end{tabular}

Ritam u glazbi definiran je kao redoslijed nizanja zvukova i tonova tj. odnos u izmjenjivanju tonova koji ovisi o duljini njihova trajanja i njihovu naglašavanju. Mjera je pravilno izmjenjivanje jednakih vremenskih odsječaka, a najmanji metrički određen dio skladbe zove se takt. Mjere mogu 
biti jednostavne (pr. dvodobne i trodobne mjere) i složene. Složene mjere dijele se na simetrične (pr. četverodobne mjere) i asimetrične (nastale zbrajanjem dvodobnih i trodobnih mjera u različitim kombinacijama) (Tomašić, 2003).

Ritam u govoru prozodijsko je obilježje koje se percipira kao pravilno pojavljivanje i izmjenjivanje istaknutih i neistaknutih jezičnih elemenata (Hrvatska enciklopedija, 2018). Govorni ritam (engl. speech rhythm) definira se kao način na koji je jezik organiziran u vremenu (Patel i sur., 2006). Škarićeva (1992) definicija prema kojoj je govor oblikovan ritmom rečenica, riječi i slogova ističe važnost ritma kao obilježja govora. Patel (2003) slijedi istu ideju te navodi da jezični ritam (engl. linguistic rhythm) oblikuju uzorak grupiranja riječi u iskazima i stanki između iskaza, uzorak trajanja slogova te uzorak naglašenih i nenaglašenih slogova. Percepcija vremenske organizacije fonema, slogova, riječi i fraza u govornom iskazu važna je za razumijevanje govora (Fujii i Wan, 2014). Jednostavno rečeno, ritam je ključan za razumijevanje govora.

Brojni stručnjaci smatraju da je ritam temelj glazbe i da je ritam osnovni princip organizacije funkcija mozga (Buzsaki, 2006; prema Patel i Iversen, 2014) te pretpostavljaju da su neuralni mehanizmi za obradu ritma drevni i urođeni (Patel i Iversen, 2014). Iz istraživanja na temu lateralizacije ritma saznaje se da o vrsti ritma ovisi koja će moždana polutka biti aktivna (Duffy, 2014). Naime obrada metričkih ritmova odvija se u lijevoj polutci mozga (Riecker i sur., 2002; prema Duffy, 2014). S druge strane desna polutka mozga zadužena je za obradu ne-metričkih ritmova (Horváth i sur., 2011; prema Duffy, 2014), točnije prednja sekundarna slušna moždana kora (Riecker i sur., 2002; prema Duffy, 2014). Otkriveno je da čeono-sljepoočna neuralna mreža izdvaja kontinuirano promjenjivu vremensku strukturu ne-metričkog ritma s nepravilnim naglascima, pa je moguće zaključiti da je ovo područje aktivno i u obradi ritma rečenice (Horváth i sur., 2011). Prema Horváth i suradnicima (2011) u percepciji vremenski strukturiranih zvučnih podražaja sudjeluju obje moždane polutke, no potrebno je više istraživanja na temu specijalizacije i interakcije između moždanih polutki. U percepciji ritma, točnije takta, neovisno o motoričkoj aktivnosti (primjerice otkucavanju ritma rukom) sudjeluje moto- rički sustav koji uključuje premotoričku moždanu koru, bazalne ganglije i dodatno motoričko polje moždane kore (Chen i sur., 2008; Grahn i Rowe, 2009; Kung i sur., 2013; prema Patel i Iversen, 2014) što upućuje na povezanost između percepcije ritma i motoričke funkcije mozga. Uz navedeno $\mathrm{u}$ analizi vremenskih sekvenci i predviđanju ili proizvodnji otkucaja u ritmu vjerojatno sudjeluje kortiko-subkortikalna neuralna mreža koju čine putamen, dodatno motoričko polje moždane kore i premotoričko polje moždane kore (Grahn, 2009). Grahn (2009) navodi da bazalni gangliji nisu aktivni samo prilikom percepcije ritma, neovisno o glazbenom iskustvu osobe ili vrsti ritma, već su nužni za uspješnu percepciju i obradu ritma, to jest takta. Mali mozak te premotoričko i dodatno motoričko polje moždane kore aktiviraju se prilikom rješavanja zadataka za produkciju ritma u kojima ispitanici trebaju otkucavati zadani ritam (Rao i sur., 2001; Schubotz i sur., 2009; prema Horváth i sur., 2011).

Afazija je stečeni jezični poremećaj uzrokovan žarišnim oštećenjem mozga, kod kojeg deficiti mogu biti prisutni u svim sastavnicama jezika (fonologiji, morfologiji, sintaksi, semantici i pragmatici) te u svim načinima izražavanja - govoru, pisanju, čitanju i pjevanju (Papathanasiou, Coppens i Potagas, 2013). Prema definicijama, uzrok afazija leži u žarišnom oštećenju mozga, a najčešći je uzrok moždani udar (Hegde, 2006) u dominantnoj, lijevoj polutci mozga. Vrste afazija različite su s obzirom na lokalizaciju oštećenja mozga i simptome koji se odražavaju na pojedinčev život i funkcioniranje u zajednici. Klasifikacije afazija se razlikuju pa tako primjerice Hegde (2006) spominje tečne i netečne, receptivne i ekspresivne te perisilvijske, ekstrasilvijske i subkortikalne afazije, dok Davis (2007) govori o Brocainoj, Wernickeovoj, globalnoj, konduktivnoj, anomičkoj, transkortikalnoj motoričkoj, transkortikalnoj senzoričkoj, miješanoj transkortikalnoj i subkortikalnoj afaziji. Simptomi se također međusobno razlikuju, no postoje opći simptomi koje je potrebno poznavati radi diferencijalne dijagnostike afazija i drugih jezičnih ili motoričkih govornih poremećaja. Hegde (2006) navodi opće simptome afazija, a to su: česta uporaba parafazija, poremećaji tečnosti govora, teškoće $u$ auditivnom razumijevanju, učestala ponavljanja fraza, riječi ili rečenica, teškoće imenovanja, aleksija te teškoće 
u imitaciji. U kontekstu ovog rada valja istaknuti neka od brojnih obilježja netečnih afazija poput usporenog govornog tempa, narušenog govornog ritma te netipičnih prozodijskih obilježja (Hegde, 2006; Papathanasiou, Coppens i Potagas, 2013).

Osim jezičnih i govornih simptoma, kod osoba $\mathrm{s}$ afazijom uočene su i poteškoće s obradom ritma (Zipse, Worek, Guarino i Shattuck-Hufnagel, 2014). Zvučni signali kraćeg trajanja poput brze izmjene konsonanata obrađuju se u lijevoj polutci mozga (Poeppel, 2003; prema Zipse i sur., 2014). Uslijed oštećenja dominantne lijeve moždane polutke, koje za posljedicu ima afaziju, javljaju se poteškoće u obradi brze izmjene zvučnih signala što se očituje kroz teškoće percepcije i produkcije ritma (Zipse i sur., 2014). Usto smatra se da je lijeva polutka mozga dominantna u procesu obrade ritma kod osoba bez neuroloških oštećenja te da je oštećenje lijeve polutke mozga uzrok poremećaja obrade ritma (Kim i Tomaino, 2008). Navedeno potvrđuje i pronalazak da su ispitanici s oštećenjem lijeve moždane polutke uspješniji u reprodukciji zadane melodije nego u ponavljanju ritamskih zadataka iz Boston testa za diferencijalnu dijagnostiku afazija (Prizl Jakovac, 2002).

Pitanje percepcije i produkcije ritma kod osoba s afazijom u središtu je istraživanja koja za cilj imaju dokazivanje učinkovitosti glazbeno terapijskih postupaka i logopedskih tretmana temeljenih na korištenju ritma (npr. Terapija melodijskom intonacijom (engl. Melodic Intonation Therapy) (Albert, Sparks i Helm, 1973), Govorno-glazbena terapija za afaziju (engl. Speech-Music Therapy for Aphasia) (Bruijn, Zielman i Hurkmans, 2005)). U literaturi se ritam ističe kao ključna komponenta u rehabilitaciji jezika i govora, a ne pjevanje kao što se ranije smatralo (Stahl i sur., 2011; Stahl i sur., 2013; prema Raglio i sur., 2016). Tomaino (2012) navodi da manipulacija ritmom može pomoći osobama $\mathrm{s}$ afazijom u prizivanju riječi, oblikovanju prozodije govora te izgovoru. Ritam je temelj organizacije pokreta na raznim razinama (Stahl i sur., 2011; Thaut, 2005; prema Raglio i sur., 2016) te može olakšati koordinaciju govornog ritma što rezultira poboljšanjem tečnosti i razumljivosti govora (Raglio i sur., 2016). U terapiji melodijskom intonacijom slogovi se izgovaraju u metrički jednakim uzorcima (primjerice u trajanju od pola dobe ili četvrtine dobe) uz otkucavanje ritma (najčešće lijevom, nedominantnom rukom) (Jonkers, Terband i Maassen, 2014). Govorni ritam produciran na taj način pravilniji je nego u prirodnom govoru (Kershenbaum, Nicholas, Hunsaker i Zipse, 2017). Rezultati istraživanja Zumbansen, Peretz i Herbert (2014; prema Curtis, Nicholas, Pittmann i Zipse, 2019), u kojem su sudjelovale tri osobe s afazijom, ukazuju na to da je melodija uz ritam važna komponenta terapije melodijskom intonacijom. Naime terapija u kojoj je govor uparen samo s otkucavanjem ritma bila je manje učinkovita od uobičajene govorne terapije, dok je logopedski tretman temeljen na korištenju ritma i melodije imao bolje rezultate i od uobičajene govorne terapije i one u kojoj je govor praćen samo otkucavanjem ritma. Curtis i suradnice (2019) u svojem su radu prikazale da su osobe s afazijom kod kojih je sposobnost percepcije i produkcije ritma očuvana imale više koristi od logopedske terapije koja je uključivala otkucavanje ritma. S druge strane kod osoba narušene sposobnosti percepcije i produkcije ritma zabilježeni su bolji rezultati nakon logopedske terapije bez otkucavanja ritma. Njihov pronalazak potkrepljuje potrebu i važnost ispitivanja percepcije i produkcije ritma prije donošenja odluke o provođenju logopedskih tretmana temeljenih na glazbenim sastavnicama i korištenju ritma. Moguće je da uspješnost terapija čija je važna komponenta otkucavanje ritma ovisi upravo o ritamskim sposobnostima osobe s afazijom (Zipse i sur., 2014). Potrebno je istaknuti da rezultati istraživanja koja su se bavila ovom temom upućuju na to da logopedske intervencije temeljene na glazbenim sastavnicama imaju snažniji utjecaj na govor nego na jezične teškoće, pa je stoga njihov utjecaj izraženiji kod osoba s afazijom i pridruženim motoričkim govornim poremećajima (Zumbansen i Tremblay, 2018).

\section{PROBLEM I CILJ ISTRAŽIVANJA}

Korištenje glazbe i glazbenih sastavnica u terapiji komunikacijskih, jezičnih i govornih poremećaja, pa tako i u terapiji osoba s neurološkim oštećenjima aktualna je tema. Uzimajući u obzir brojna obilježja afazije i malen broj istraživanja na ovu temu, potrebno je kritički promišljati i o učinkovitosti terapijskih postupaka temeljenih na korištenju glazbe i glazbenih sastavnica i o njihovoj teorijskoj utemeljenosti. 
Cilj provedenog istraživanja bio je ispitati postoje li teškoće percepcije i produkcije ritma kod osoba s afazijom, utvrditi postoje li razlike između percepcije i produkcije ritma kod iste skupine ispitanika te postoji li povezanost između auditivnog razumijevanja i sposobnosti percepcije i produkcije ritma kod obiju skupina ispitanika.

\section{HIPOTEZE}

Sukladno cilju istraživanja postavljene su sljedeće hipoteze:

H1: Osobe s afazijom bit će uspješnije na primijenjenim zadacima za percepciju ritma nego na zadacima za produkciju ritma.

H2: Kontrolna skupina ispitanika postići će viši rezultat na zadacima za ispitivanje percepcije i produkcije ritma od osoba s afazijom.

H3: Postoji povezanost između postignuća na zadacima auditivnog razumijevanja riječi i rečenica te sposobnosti percepcije i produkcije ritma kod obiju skupina ispitanika.

\section{METODE RADA}

\section{Uzorak ispitanika}

U provedenom istraživanju sudjelovalo je ukupno 20 ispitanika - 10 ispitanika s afazijom i 10 ispitanika bez afazije. Ispitano je 14 muškaraca i 6 žena, starosne dobi od 24 do 68 godina (prosječna dob 44 godine $(S D=14,7)$. Materinski je jezik svih ispitanika hrvatski jezik. Desna je ruka dominantna svim ispitanicima s afazijom. Ispitane su osobe s dijagnozom afazije netečnog tipa kod kojih je očuvano jezično razumijevanje i sposobnost praćenja uputa. Sposobnost jezičnog razumijevanja ispitana je zadacima auditivnog razumijevanja riječi i rečenica preuzetima iz Hrvatskog testa za afaziju, a dobiveni su rezultati uspoređeni s vrijednostima dobivenima tijekom izrade preliminarne inačice testa. Svi ispitanici s afazijom doživjeli su jedan moždani udar u lijevoj moždanoj polutci; osmero ispitanika doživjelo je ishemijski, a dvoje hemoragijski moždani udar. Vrijeme proteklo od trenutka moždanog udara do trenutka ispitivanja iznosi od jednog do 72 mjeseca. Tri ispitane osobe s afazijom imaju desnostranu hemiplegiju, a desnostranu hemiparezu ima sedmero njih. Prema podacima iz medicinske dokumentacije ispitanika (nalazi neurologa i fizijatra) kod ispitanih osoba nije prisutna apraksija ekstremiteta. Iz logopedskih nalaza ispitanih osoba saznaje se da četiri ispitanika s afazijom dodatno imaju dizartriju i/ ili govornu apraksiju. Kod samo jednog ispitanika uočeno je nedijagnosticirano oštećenje sluha, pa je prilikom ispitivanja dodatno pojačana glasnoća prezentiranih zvučnih primjera. Osam ispitanika ima glazbeno iskustvo, a 12 ih je izjavilo da nema glazbeno iskustvo. Za potrebe istraživanja ispitani su pacijenti Odjela za rehabilitaciju kraniocerebralnih bolesnika i akutnu neurologiju, Specijalne bolnice za medicinsku rehabilitaciju Krapinske Toplice te Kabineta za komunikacijske poremećaje odraslih, Centra za rehabilitaciju Edukacijskorehabilitacijskog fakulteta Sveučilišta u Zagrebu, uključeni u logopedsku terapiju za vrijeme provođenja ovog istraživanja. Ispitanici kontrolne skupine izabrani su prema kriterijima spola, dobi i glazbenog iskustva. Podaci o parovima ispitanika $\mathrm{s}$ afazijom $\mathrm{i}$ ispitanika iz kontrolne skupine prikazani su u Tablici 2.

\section{Opis varijabli}

Ukupno 15 varijabli korištenih u ovom istraživanju definirano je prema zadacima iz Protokola $z a$ ispitivanje percepcije i produkcije ritma kod osoba $s$ afazijom te zadacima iz Hrvatskog testa za afazi$j u$. To su: varijable ukupnog broja točnih odgovora na zadacima za percepciju ritma i na zadacima za produkciju ritma prema ritamskim mjerama ovisno o tome radi li se o dvodobnoj, trodobnoj, četverodobnoj ili složenim mjerama, varijabla ukupnog broja točnih odgovora na zadacima za produkciju ritma, varijabla trajanja provedbe Protokola te varijable rezultata ostvarenih na zadacima auditivnog razumijevanja riječi, rečenica i ukupnog rezultata na zadacima auditivnog razumijevanja. Varijable korištene u statističkoj obradi rezultata obiju skupina ispitanika i njihove šifre navedene su u Tablici 3.

\section{Opis ispitnog materijala}

Protokol za ispitivanje percepcije i produkcije ritma kod osoba s afazijom (u daljnjem tekstu: Protokol) osmišljen je i izrađen u svrhu ispitivanja percepcije i produkcije ritma kod osoba s afazijom. 
Hrvatska revija za rehabilitacijska istraživanja 2020, Vol 56, br. 1, str. 19-32

\begin{tabular}{|c|c|c|c|c|c|c|c|c|c|c|c|c|}
\hline \multirow{5}{*}{ 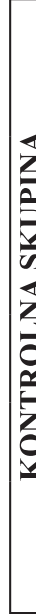 } & 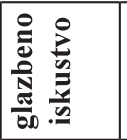 & $\mathscr{\Xi}$ & $\Xi$ & تृ & $\mathscr{\Xi}$ & 푱 & 풍 & $\stackrel{\mathscr{I}}{\Xi}$ & శే & $\mathscr{\Xi}$ & $\stackrel{\mathscr{g}}{\Xi}$ & $\begin{array}{l}\tilde{D} \\
\text { है }\end{array}$ \\
\hline & 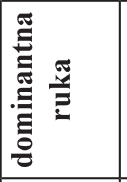 & 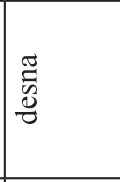 & 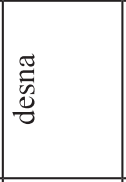 & 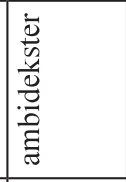 & 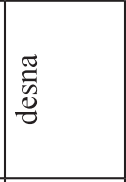 & 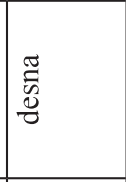 & 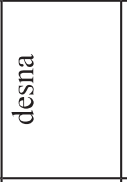 & $\stackrel{\tilde{J}}{:}$ & 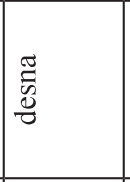 & 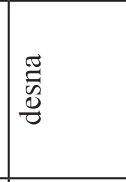 & 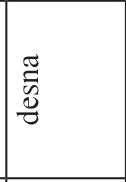 & 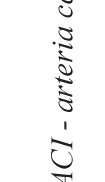 \\
\hline & $\stackrel{\circ}{\circ}$ & 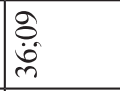 & $\begin{array}{l}8 \\
0 \\
0 \\
6\end{array}$ & $\begin{array}{l} \\
\text { di } \\
\tilde{n}\end{array}$ & $\frac{\hat{m}}{\dot{m}}$ & 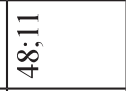 & \begin{tabular}{|l|} 
\\
0 \\
$\dot{0}$ \\
$\dot{\alpha}$
\end{tabular} & $\begin{array}{l}\dot{d} \\
\dot{n} \\
\dot{n}\end{array}$ & $\begin{array}{l}\vec{\Xi} \\
\dot{\sim} \\
\dot{d}\end{array}$ & $\begin{array}{l}8 \\
\dot{\delta} \\
\dot{\delta}\end{array}$ & 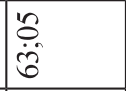 & \\
\hline & \begin{tabular}{|l}
0 \\
\end{tabular} & N & $\Sigma$ & $\Sigma$ & $\Sigma$ & $\Sigma$ & $\Sigma$ & $\mathrm{N}$ & $\Sigma$ & $\Sigma$ & $\mathrm{N}$ & \\
\hline & 窇 & $\hat{\Sigma}$ & $\sum$ & 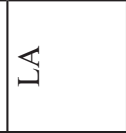 & $\tilde{z}$ & $\sqrt{5}$ & $\approx$ & $\exists$ & 它 & A & $\geq$ & 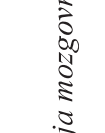 \\
\hline & 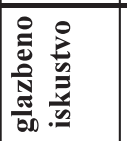 & $\cong$ & $\Xi$ & ت & $\mathscr{I}$ & శี & 푱 & $\cong$ & శ & $\stackrel{g}{\exists}$ & $\mathscr{g}$ & $\begin{array}{l}\text { हे } \\
\text { हे }\end{array}$ \\
\hline & 部 & 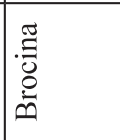 & \begin{tabular}{|l}
$\frac{\pi}{\pi}$ \\
$\frac{\pi}{\pi}$ \\
$\frac{0}{0}$ \\
$\infty$
\end{tabular} & 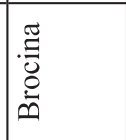 & 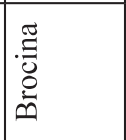 & 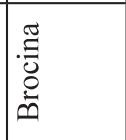 & 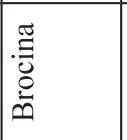 & 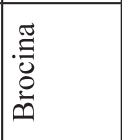 & 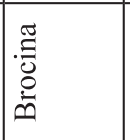 & 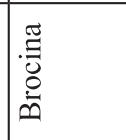 & 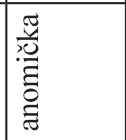 & 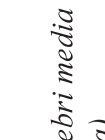 \\
\hline & 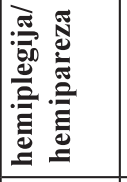 & 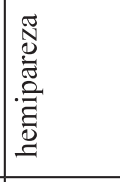 & 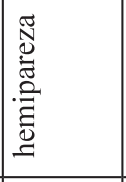 & 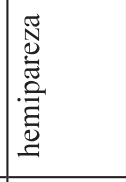 & 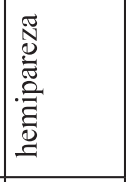 & 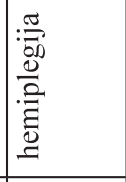 & 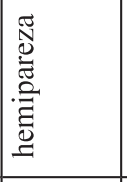 & 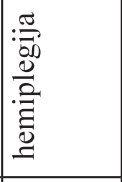 & 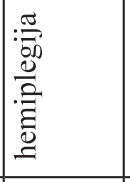 & 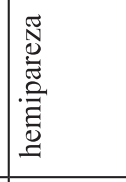 & 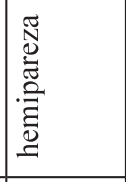 & 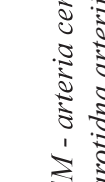 \\
\hline 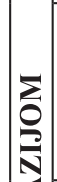 & 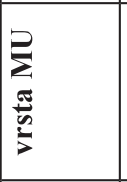 & 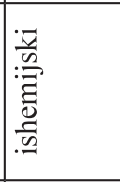 & 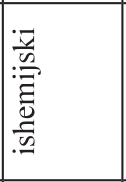 & 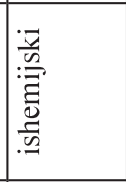 & 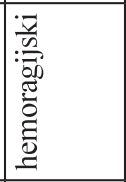 & 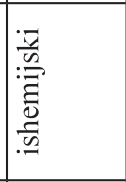 & 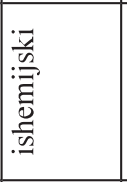 & 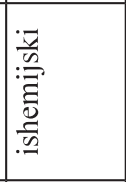 & 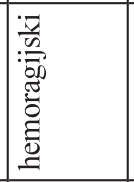 & 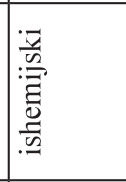 & 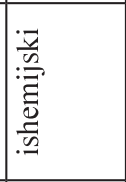 & 8 \\
\hline 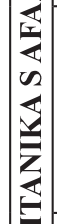 & 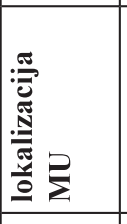 & 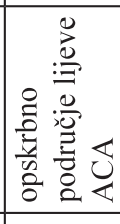 & 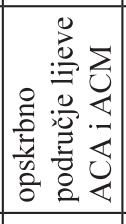 & 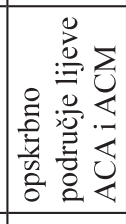 & 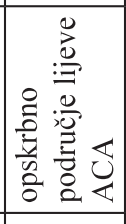 & 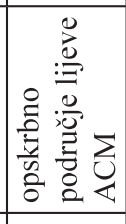 & 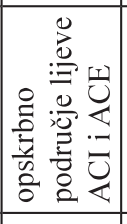 & 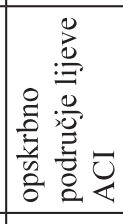 & 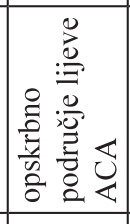 & 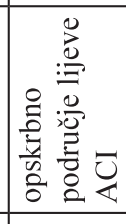 & 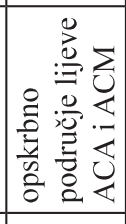 & 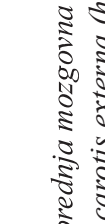 \\
\hline$\overline{\bar{\Omega}}$ & 물ㄹ & - & - & - & - & - & - & - & - & - & - & \\
\hline 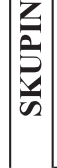 & 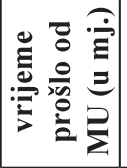 & $\pi$ & $\cong$ & in & ల్ల & $\sim$ & - & $m$ & t & 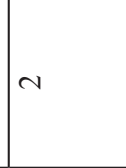 & ஓ & 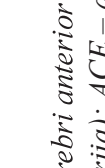 \\
\hline & 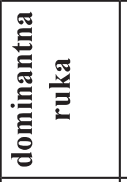 & $\begin{array}{l}\frac{\sigma}{5} \\
\frac{\tilde{z}}{\delta} \\
\frac{8}{\delta}\end{array}$ & 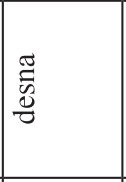 & 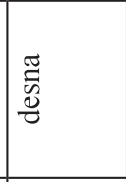 & $\begin{array}{l}\frac{\pi}{5} \\
\frac{\tilde{z}}{\partial} \\
\frac{8}{\partial}\end{array}$ & 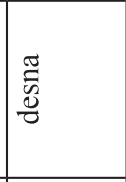 & 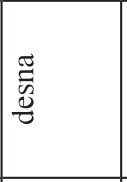 & 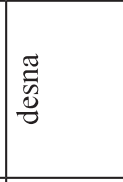 & 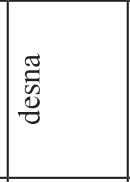 & 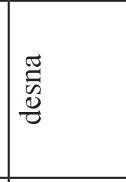 & 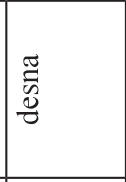 & 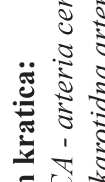 \\
\hline & $\stackrel{\circ}{\circ}$ & $\begin{array}{l}\overline{0} \\
\dot{\phi} \\
\text { in }\end{array}$ & $\begin{array}{l}7 \\
00 \\
0\end{array}$ & $\begin{array}{l}8 \\
\dot{m} \\
\dot{m}\end{array}$ & \begin{tabular}{|l|}
\multirow{2}{*}{} \\
$\hat{\tilde{n}}$ \\
\end{tabular} & $\begin{array}{l} \\
\dot{a} \\
\dot{q}\end{array}$ & 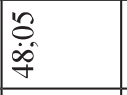 & $\begin{array}{l}\stackrel{0}{\circ} \\
\dot{m}\end{array}$ & 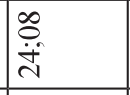 & 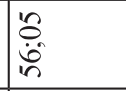 & $\begin{array}{l}\tilde{\sigma} \\
\dot{\sigma}\end{array}$ & $\overline{\bar{c}}$ \\
\hline & 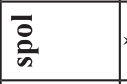 & $\mathbb{N}$ & $\Sigma$ & $\Sigma$ & $\Sigma$ & $\Sigma$ & $\Sigma$ & $\mathrm{N}$ & $\Sigma$ & $\Sigma$ & $\mathrm{N}$ & $\cong 5$ \\
\hline & 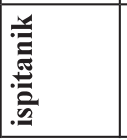 & $y$ & 2 & $\stackrel{2}{N}$ & פִ & $\cong$ & $\stackrel{m}{2}$ & $\ddot{\psi}$ & $\ddot{\partial}$ & 文 & $\because$ & 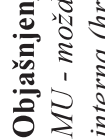 \\
\hline
\end{tabular}


Tablica 3. Varijable korištene u statističkoj obradi podataka i njihove šifre

\begin{tabular}{|l|l|}
\hline Šifra varijabli & Naziv varijabli \\
\hline perc_rit_ukup_10 & ukupan broj točnih odgovora na zadacima za percepciju ritma \\
\hline perc_rit_ukup_10_posto & ukupan broj točnih odgovora na zadacima za percepciju ritma, u postotcima \\
\hline prod_rit_dvo_ukup_6 & ukupan broj točnih odgovora - produkcija ritma - dvodobna mjera \\
\hline prod_rit_tro_ukup_6 & ukupan broj točnih odgovora - produkcija ritma - trodobna mjera \\
\hline prod_rit_četv_ukup_6 & ukupan broj točnih odgovora - produkcija ritma - četverodobna mjera \\
\hline prod_rit_slož_ukup_6 & ukupan broj točnih odgovora - produkcija ritma - složene mjere \\
\hline prod_rit_ukup_24 & ukupan broj točnih odgovora na zadacima za produkcija ritma \\
\hline prod_rit_ukup_24_posto & ukupan broj točnih odgovora na zadacima za produkcija ritma, u postocima \\
\hline trajanje_protokola & trajanje provedbe Protokola \\
\hline aud_raz_riječi & rezultat na zadatku auditivnog razumijevanja riječi \\
\hline aud_raz_reč & rezultat na zadatku auditivnog razumijevanja rečenica \\
\hline aud_raz_ukup & ukupni rezultat na zadacima auditivnog razumijevanja \\
\hline aud_raz_riječi_posto & rezultat na zadatku auditivnog razumijevanja riječi, u postocima \\
\hline aud_raz_reč_posto & rezultat na zadatku auditivnog razumijevanja rečenica, u postocima \\
\hline aud_raz_ukup_posto & ukupni rezultat na zadacima auditivnog razumijevanja, u postocima \\
\hline
\end{tabular}

Prvim dijelom Protokola ispituju se opće informacije o ispitaniku. Uz demografska pitanja postavljena su pitanja o moždanom udaru i njegovim posljedicama, govorno-jezičnim teškoćama, logopedskoj terapiji i drugim medicinskim dijagnozama te pitanja o glazbenom iskustvu ispitanika.

Zadaci za percepciju ritma čine drugi dio Protokola. Ova skupina zadataka sastoji se od 10 ispitnih čestica i dviju čestica za uvježbavanje. Jednu ispitnu česticu čine dva ritamska primjera koji mogu biti isti ili različiti. Ritamski primjeri za percepciju ritma poredani su prema složenosti.

Zadaci za produkciju ritma čine treći dio Protokola. Ovaj dio Protokola podijeljen je u četiri podskupine zadataka prema ritamskoj mjeri u kojoj su zadaci zapisani: zadaci za produkciju ritma u dvodobnoj, trodobnoj, četverodobnoj te u složenim simetričnim i asimetričnim mjerama. Svaka podskupina sastoji se od šest ispitnih čestica i jedne čestice za uvježbavanje. Ritamski primjeri za produkciju ritma poredani su prema složenosti.

Uz Protokol stvoreni su zvučni zapisi ritamskih primjera iz ispitnih zadataka. Ritamski primjeri zapisani su u računalnom programu za glazbenu notaciju MuseScore 2. Broj otkucaja u jednom primjeru nije veći od devet jer je jedan od kriterija pri izradi ritamskih primjera bio prosječni kapacitet radnog pamćenja koji iznosi $7 \pm 2$ čestice (tzv. Millerov broj). Zvučni zapisi ritamskih primjera programirani su u računalnom programu za glazbenu produkci- ju Ableton Live 10. Kreirani zvučni zapisi u MP3formatu uvršteni su na popise za reprodukciju u računalnom programu Foobar2000 v1.4.

$\mathrm{U}$ ispitivanju su korištena i dva zadatka iz Hrvatskog testa za afaziju. Hrvatski test za afaziju osmišljen je i prilagođen prema Aachen Aphasia Testu (Huber, Poeck, Willmes, 1983). Preliminarna inačica testa izrađena je u okviru projekta "Afazije i traumatska oštećenja mozga" voditeljice Tatjane Prizl Jakovac (MZOS 2006-2011; br.00132350), koji je dio internacionalnog i multidisciplinarnog projekta "REhabilitation and recovery of peopLE with Aphasia after StrokE" (RELEASE; voditeljica: Marian C. Brady, Glasgow Caledonian University, National Institute of Health Research, NIHR; HS\&DR Project: 14/04/22 (2015-2018)). Ovaj se test razvija i koristi u istraživačke svrhe u Kabinetu za komunikacijske poremećaje odraslih, Centra za rehabilitaciju Edukacijsko-rehabilitacijskog fakulteta Sveučilišta u Zagrebu. U ovom su istraživanju osobe iz skupine ispitanika s afazijom i prosječnih govornika ispitane zadatkom auditivnog razumijevanja riječi i zadatkom auditivnog razumijevanja rečenica. Za ispitivanje auditivnog razumijevanja riječi i rečenica potrebna je ispitna lista riječi i rečenica koje se čitaju ispitaniku te slikovni predlošci na kojima ispitanik treba prepoznati riječ ili rečenicu koju je ispitivač pročitao. Za svaki su primjer ispitaniku predstavljena četiri crteža od kojih jedan predstavlja točan odgovor, dva crteža predstavljaju fonemski i semantički distraktor, a jedan 
crtež nije jezično sličan ciljanoj riječi. Ispitivanje ovim zadacima brzo je i jednostavno, a daje uvid u razinu auditivnog razumijevanja ispitanika, što je važno zbog praćenja uputa u daljnjem ispitivanju Protokolom.

\section{Način provođenja istraživanja}

Osobe s afazijom ispitane su na Odjelu za rehabilitaciju kraniocerebralnih bolesnika i akutnu neurologiju, Specijalne bolnice za medicinsku rehabilitaciju Krapinske Toplice te u Kabinetu za komunikacijske poremećaje odraslih, Centra za rehabilitaciju Edukacijsko-rehabilitacijskog fakulteta Sveučilišta u Zagrebu. Ispitanici iz kontrolne skupine ispitani su prema dogovoru. Ispitivanje je provedeno u mirnoj prostoriji nasamo s ispitivačem tijekom jednog susreta u trajanju do 20 minuta. $U$ ispitivanju je korišteno osobno računalo uz zvučnike za reprodukciju zvučnih zapisa, Informirani pristanak za sudjelovanje u istraživanju, Protokol za ispitivanje percepcije i produkcije ritma kod osoba s afazijom te ispitna lista riječi i rečenica uz slikovne materijale za provođenje zadataka auditivnog razumijevanja riječi i rečenica iz Hrvatskog testa za afaziju. Cijeli postupak ispitivanja sniman je video kamerom radi naknadne analize odgovora ispitanika.

Istraživanje je provedeno u skladu s pravilima i normama propisanima u Etičkom kodeksu Sveučilišta u Zagrebu. Prije početka ispitivanja ispitanicima je opisan postupak ispitivanja te su ispitanici potpisali Informirani pristanak za sudjelovanje u istraživanju.

Uvidom u medicinsku dokumentaciju prikupljeni su osobni podaci, podaci o moždanom udaru i njegovim posljedicama, govorno-jezičnim teškoćama, logopedskoj terapiji i drugim medicinskim dijagnozama ispitanika s afazijom. Kroz strukturirani intervju prikupljeni su isti podaci o ispitanicima iz kontrolne skupine. Podaci o glazbenom iskustvu obiju skupina ispitanika prikupljeni su metodom strukturiranog intervjua.

Ispitanici su ispitani zadacima auditivnog razumijevanja riječi i rečenica, preuzetima iz Hrvatskog testa za afaziju. U ispitivanju je korištena ispitna lista riječi i rečenica koja ujedno služi i za bodovanje odgovora ispitanika te slikovni materijal prezentiran ispitanicima.
Percepcija ritma ispitana je tako što su ispitanici nakon slušanja parova ritamskih primjera reproduciranih s osobnog računala odgovarali na pitanje jesu li ritmovi koje su čuli isti ili različiti (Slika 1.). Ispitanici su prije odgovaranja na ispitne čestice odgovorili na dvije čestice za uvježbavanje uz ispitivača. Ritamski su primjeri samo jednom prezentirani ispitanicima. Odgovori su nakon ispitivanja bodovani kao točni ili netočni.

\begin{tabular}{|c|c|c|c|c|c|}
\hline r.br. & $\begin{array}{c}\text { ritamski } \\
\text { primjer } 1\end{array}$ & $\begin{array}{l}\text { ritamski } \\
\text { primjer } 2\end{array}$ & isto & različito & $\begin{array}{c}\text { nema } \\
\text { odgovora }\end{array}$ \\
\hline 1. & & & isti & & \\
\hline 2. & & & & različiti & \\
\hline
\end{tabular}

Slika 1. Primjeri zadataka za percepciju ritma

Produkcija ritma ispitana je na sličan način kao i percepcija ritma. Ispitanici su najprije uz ispitivača odgovorili na jednu česticu za uvježbavanje. Zatim su slušali ritamske primjere za produkciju ritma (Slika 2.) reproducirane s osobnog računala te su rukom otkucavali zadani ritam onako kako su ga čuli. Ispitanici su mogli sami odlučiti kojom će rukom otkucavati ritam. Tako je osam ispitanika s afazijom ritam otkucavalo lijevom nedominantnom rukom (ispitanici kod kojih je prisutna hemiplegija ili hemipareza ekstremiteta), a dvoje je za otkucavanje ritma koristilo desnu dominantnu ruku (ispitanici koji su se oporavili od hemiplegije ili hemipareze ekstremiteta). Odgovori ispitanika bodovani su kao točni ili netočni, a otkucani ritmovi koji su se razlikovali od zadanih zapisani su radi naknadne kvalitativne analize.

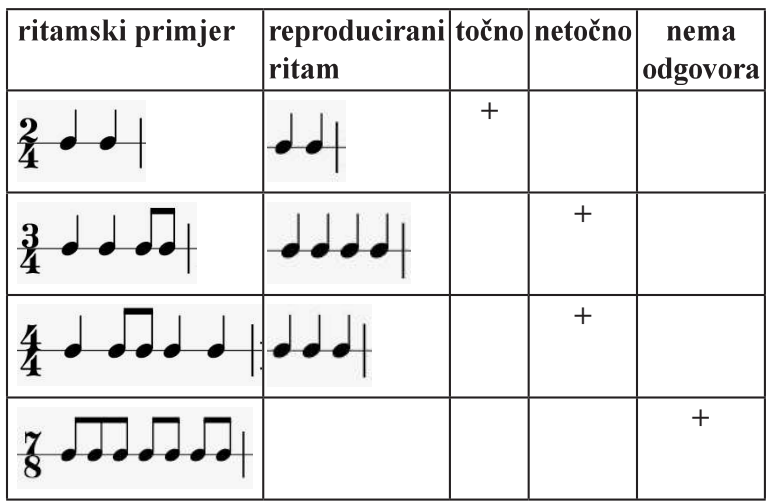

Slika 2. Primjeri zadataka za produkciju ritma te odgovora jednog ispitanika 
Ispitanicima s afazijom u prosjeku je bilo potrebno 10 minuta i 37 sekundi (S.D. $=0: 02: 15$ ) za rješavanje zadataka za percepciju i produkciju ritma iz Protokola za ispitivanje percepcije $i$ produkcije ritma kod osoba s afazijom, dok su ispitanici iz kontrolne skupine iste zadatke rješavali u prosjeku za 7 minuta i 16 sekundi (S.D. $=0: 01: 21)$.

\section{Metode obrade podataka}

Prikupljeni podaci obrađeni su u računalnom programu IBM ${ }^{\circledR} S P S S^{\circledR}$ Statistics (Version 20; 2011). Uzimajući u obzir malen broj ispitanika te nepravilnu distribuciju rezultata odabrani su neparametrijski statistički postupci i metode. Primijenjena su tri načina obrade podataka. Mann-Whitneyev U-test korišten je za usporedbu rezultata između skupina ispitanika, Wilcoxonov test korišten je za usporedbu rezultata unutar skupina, a Spearmanov koeficijent korelacije korišten je za potvrđivanje povezanosti među varijablama.

\section{REZULTATI I RASPRAVA}

\section{Rezultati dobiveni statističkom obradom prikupljenih podataka}

Osnovni statistički pokazatelji: aritmetička sredina, standardna devijacija te minimalni i maksimalni rezultati izračunati za varijable rezultata ostvarenih na zadacima Protokola za percepciju $i$ produkciju ritma kod osoba s afazijom i zadacima auditivnog razumijevanja riječi i rečenica prikazani su u Tablici 4.

\section{Testiranje hipoteza}

Wilcoxonov test ekvivalentnih parova primijenjen je kako bi se otkrilo postoji li statistički značajna razlika između sposobnosti percepcije i produkcije ritma kod osoba s afazijom. Rezultati upućuju na postojanje statistički značajne razlike između sposobnosti percepcije i produkcije ritma kod osoba s afazijom $(Z=-2,803 ; p=0,005<0,05)$ (Slika 3.). Prilikom rješavanja zadataka za produkciju ritma opterećenje nije samo na slušnom radnom pamćenju, kao prilikom rješavanja zadataka za percepciju ritma, već je potrebno i motoričko planiranje i izvedba odgovora (Zipse i sur., 2014). Navedeno ove zadatke čini složenijima, naročito za osobe s afazijom kod kojih su često uz govorne i jezične teškoće prisutne i teškoće pamćenja te motoričke teškoće $u$ vidu brzine i preciznosti izvođenja sekvenci pokreta. Ovime je prihvaćena Prva hipoteza (H1) da su osobe s afazijom uspješnije u rješavanju zadataka za percepciju ritma nego zadataka za produkciju ritma.

Mann-Whitneyevim testom uspoređeni su rezultati na zadacima za percepciju i produkciju ritma među skupinama ispitanika. Ovim je testom dokazana statistički značajna razlika između postignuća skupine osoba s afazijom i kontrolne skupine ispitanika na zadacima za percepciju ritma $(\mathrm{U}=$ $4,000 ; \mathrm{p}=0,000<0,05)$, zadacima za produkciju ritma u dvodobnoj mjeri $(\mathrm{U}=6,500 ; \mathrm{p}=0,001<$ $0,05)$, trodobnoj mjeri $(\mathrm{U}=19,000 ; \mathrm{p}=0,017<$ $0,05)$, četverodobnoj mjeri $(U=16,500 ; p=0,009$ $<0,05)$, složenim ritamskim mjerama $(U=8,500 ; p$ $=0,001<0,05)$ te $u$ ukupnom postignuću na zadacima za produkciju ritma $(\mathrm{U}=7,000 ; \mathrm{p}=0,001<$ 0,05) (Slika 4).

Tablica 4. Osnovni statistički pokazatelji primijenjenih varijabli

\begin{tabular}{|c|c|c|c|c|c|c|c|c|c|c|}
\hline \multirow[t]{2}{*}{ Varijable } & \multicolumn{5}{|c|}{ OSOBE S AFAZIJOM } & \multicolumn{5}{|c|}{ KONTROLNA SKUPINA } \\
\hline & $\mathbf{N}$ & Min. & Maks. & A.S. & S.D. & $\mathbf{N}$ & Min. & Maks. & A.S. & S.D. \\
\hline perc_rit_ukup_10 & 10 & 3 & 9 & 5,90 & 1,969 & 10 & 8 & 10 & 9,60 & 0,699 \\
\hline prod_rit_dvo_ukup_6 & 10 & 0 & 4 & 2,20 & 1,549 & 10 & 2 & 6 & 5,00 & 0,247 \\
\hline prod_rit_tro_ukup_6 & 10 & 0 & 5 & 2,40 & 1,713 & 10 & 2 & 6 & 4,30 & 1,252 \\
\hline prod_rit_četv_ukup_6 & 10 & 0 & 6 & 2,40 & 1,897 & 10 & 3 & 6 & 4,60 & 1,075 \\
\hline prod_rit_slož_ukup_6 & 10 & 0 & 3 & 0,40 & 0,966 & 10 & 0 & 6 & 3,40 & 1,838 \\
\hline prod_rit_ukup_24 & 10 & 1 & 18 & 7,40 & 5,147 & 10 & 10 & 24 & 17,30 & 4,692 \\
\hline aud_raz_riječi & 10 & 4 & 30 & 23,00 & 7,616 & 10 & 30 & 30 & 30,00 & 0,00 \\
\hline aud_raz_reč & 10 & 11 & 29 & 20,40 & 6,363 & 10 & 27 & 30 & 28,70 & 1,160 \\
\hline aud_raz_ukup & 10 & 15 & 59 & 43,40 & 13,310 & 10 & 57 & 60 & 58,70 & 1,160 \\
\hline
\end{tabular}

$\mathrm{N}$ - broj ispitanika, Min. - najniža vrijednost, Maks. - najviša vrijednost, A. S. - aritmetička sredina, S. D. - standardna devijacija 


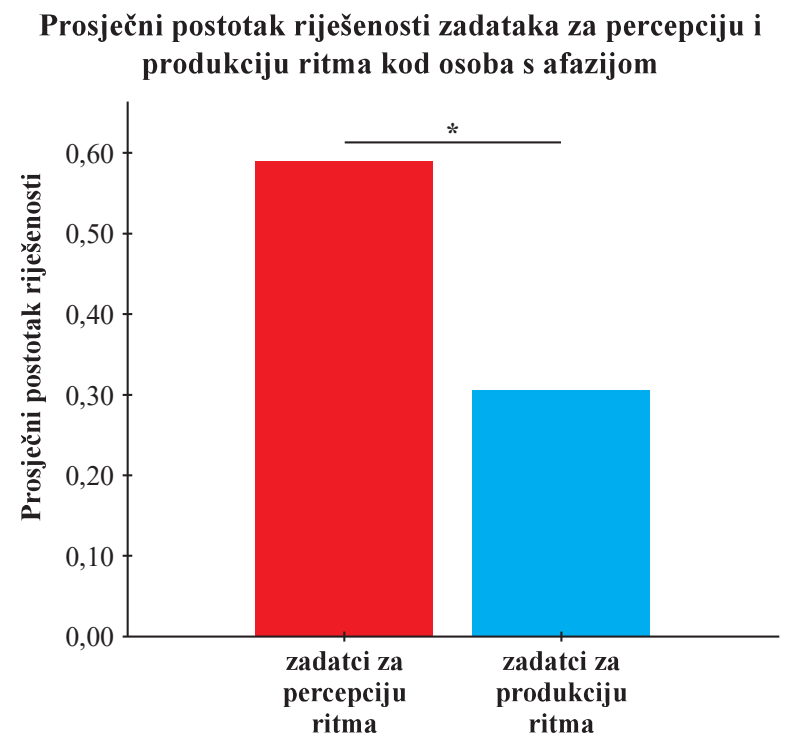

Slika 3. Prosječni postotak riješenosti zadataka za percepciju i produkciju ritma kod osoba s afazijom statistički se značajno razlikuje $\left({ }^{*} p<0,05\right)$

Sukladno očekivanjima, ispitanici kontrolne skupine bez neurološkog oštećenja postigli su više rezultate od ispitanih osoba s afazijom. Zipse i suradnici (2014) također izvještavaju o razlici u postignuću na ritamskim zadacima između skupina. U njihovu je istraživanju kontrolna skupina ispitanika bila bolja od skupine ispitanika s afazijom na tri vrste ritamskih zadataka: otkucavanju ritma uz kratke ritamske primjere, otkucavanju istih ritmova prema sjećanju te razlikovanju prezentiranih parova ritmova. Rezultati dobiveni ovim istraživanjem potvrđuju Drugu hipotezu (H2) da kontrolna skupina ispitanika postiže viši rezultat na zadacima za ispitivanje percepcije i produkcije ritma od osoba s afazijom.

Mann-Whitneyevim testom potvrđeno je da skupina prosječnih govornika postiže statistički značajno bolje rezultate na zadacima auditivnog razumijevanja riječi $(U=10,000 ; p=0,001<0,05)$ i rečenica $(U=12,000 ; p=0,004<0,05)$, te ukupno $(U=6,500 ; p=0,001<0,05)$ od skupine osoba s afazijom (Tablica 5 i Tablica 6). Moguće je da je diskrepancija u dobivenim rezultatima posljedica osjetljivosti testa na razlike u razumijevanju između skupine prosječnih govornika te osoba s afazijom, no ne ukazuje na teškoće razumijevanja uputa kod osoba s afazijom. Naposljetku računanjem Spearmanovog koeficijenta korelacije utvrđe- no je da ne postoji statistički značajna povezanost između postignuća na zadacima auditivnog razumijevanja riječi i rečenica i postignuća na zadacima za percepciju i produkciju ritma kod obiju skupina ispitanika (Tablica 7).

Zadaci auditivnog razumijevanja riječi i rečenica provedeni su s ciljem ispitivanja receptivnog jezika ispitanika te procjene njihove sposobnosti praćenja verbalnih uputa koja je ključna za praćenje zadataka Protokola za ispitivanje percepcije $i$ produkcije ritma kod osoba s afazijom. U radovima sličnima ovome navodi se kako se otkucavanje ritma može dovesti u vezu s motorikom govora, a ne s jezičnim razumijevanjem te kako su logopedski tretmani u kojima se koristi otkucavanje ritma primjereni i uspješni u terapiji osoba s motoričkim govornim poremećajima poput govorne apraksije

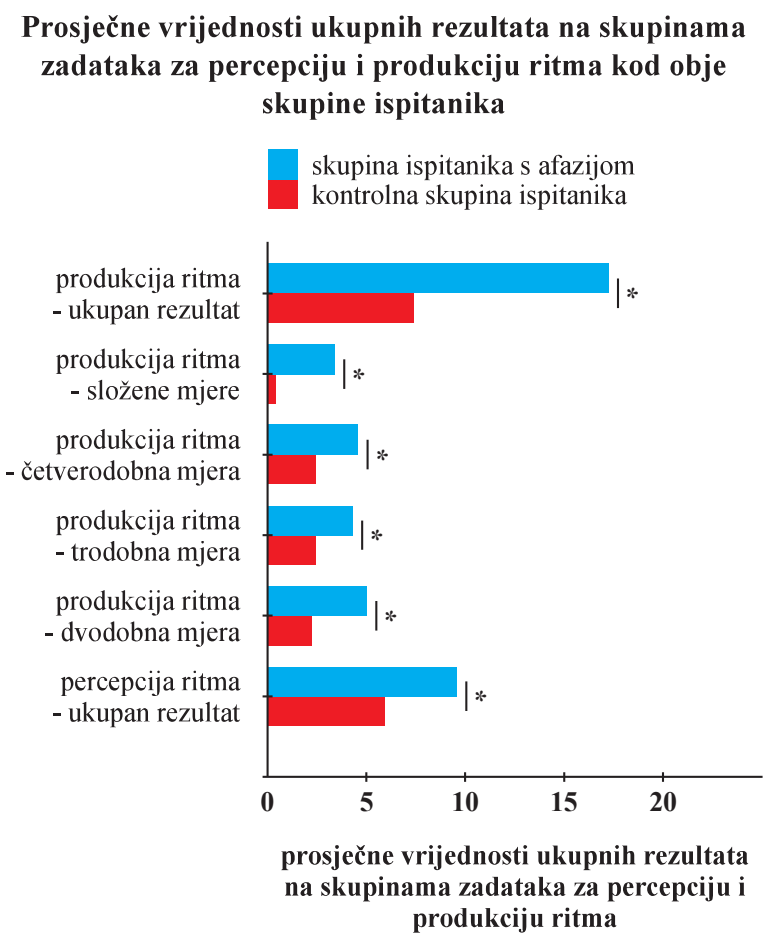

Slika 4. Prosječne vrijednosti ukupnih rezultata na skupinama zadataka za percepciju i produkciju ritma kod obje skupine ispitanika statistički se značajno razlikuju ( $\left.{ }^{*} p<0,05\right)$

Napomena: maksimalni rezultat za "produkcija ritma-ukupan rezultat" je 24, za "produkcija ritma - složene mjere", "produkcija ritma - četverodobna mjera", "produkcija ritma-trodobna mjera" $i$ "produkcija ritma - dvodobna mjera" je 6, a za "percepcija ritma-ukupan rezultat" je 10. 
Tablica 5. Podaci iz logopedske anamneze ispitanika s afazijom i rezultati ostvareni na zadacima auditivnog razumijevanja te na zadacima za percepciju i produkciju ritma

\begin{tabular}{|c|c|c|c|c|c|c|c|c|c|c|c|c|c|c|c|c|}
\hline \multicolumn{17}{|c|}{ SKUPINA ISPITANIKA S AFAZIJOM } \\
\hline \multirow[b]{2}{*}{ 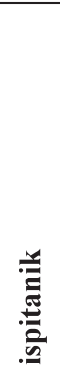 } & \multirow[b]{2}{*}{$\frac{\partial}{n}$} & \multirow[b]{2}{*}{8} & \multirow[b]{2}{*}{$\begin{array}{l}: \frac{\sigma}{\vec{J}} \\
\frac{\pi}{\sigma}\end{array}$} & \multirow[b]{2}{*}{ 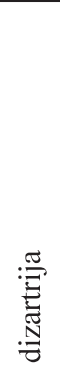 } & \multirow[b]{2}{*}{ 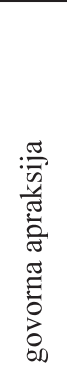 } & \multirow[b]{2}{*}{ 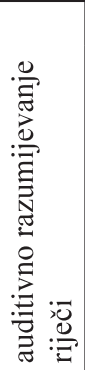 } & \multirow[b]{2}{*}{ 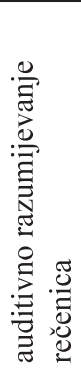 } & \multirow[b]{2}{*}{ 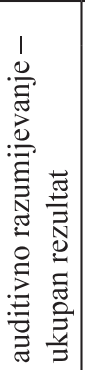 } & \multirow[b]{2}{*}{ 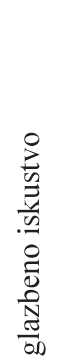 } & \multirow[b]{2}{*}{ 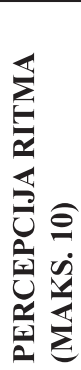 } & \multicolumn{5}{|c|}{ PRODUKCIJA RITMA } & \multirow[b]{2}{*}{ 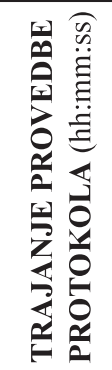 } \\
\hline & & & & & & & & & & & 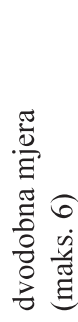 & 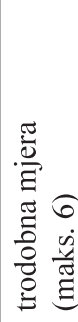 & 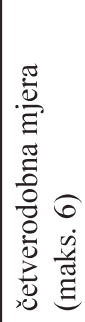 & 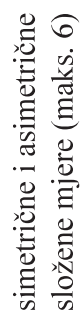 & 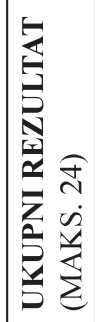 & \\
\hline VK & $\bar{Z}$ & $36 ; 01$ & Brocina & ne & ne & 30 & 29 & 59 & ne & 9 & 3 & 3 & 4 & 0 & 10 & $0: 11: 39$ \\
\hline JV & $\mathrm{M}$ & $68 ; 11$ & globalna & ne & $\mathrm{da}$ & 4 & 11 & 15 & ne & 5 & 1 & 0 & 0 & 0 & 1 & $0: 12: 20$ \\
\hline ŽKK & M & $33 ; 00$ & Brocina & $\mathrm{da}$ & ne & 27 & 21 & 48 & $\mathrm{da}$ & 9 & 4 & 5 & 6 & 3 & 18 & $0: 10: 00$ \\
\hline DG & M & $32 ; 05$ & Brocina & ne & $\mathrm{da}$ & 28 & 29 & 57 & ne & 5 & 1 & 2 & 1 & 1 & 5 & 0:08:00 \\
\hline $\mathbf{J B}$ & $\mathrm{M}$ & $49 ; 06$ & Brocina & ne & ne & 19 & 12 & 31 & $\mathrm{da}$ & 4 & 3 & 2 & 3 & 0 & 8 & $0: 10: 30$ \\
\hline PB & $\mathrm{M}$ & $48 ; 05$ & Brocina & ne & ne & 24 & 21 & 45 & $\mathrm{da}$ & 6 & 1 & 4 & 4 & 0 & 9 & 0:07:48 \\
\hline $\mathbf{A K}$ & $\check{Z}$ & $30 ; 10$ & Brocina & ne & ne & 21 & 17 & 38 & ne & 3 & 1 & 1 & 1 & 0 & 3 & $0: 12: 12$ \\
\hline DK & $\mathrm{M}$ & $24 ; 08$ & Brocina & $\mathrm{da}$ & $\mathrm{da}$ & 23 & 16 & 39 & $\mathrm{da}$ & 7 & 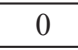 & 0 & 1 & 0 & 1 & $0: 08: 44$ \\
\hline $\mathbf{A L}$ & $\mathrm{M}$ & $56 ; 05$ & Brocina & ne & ne & 24 & 24 & 48 & ne & 5 & 4 & 3 & 3 & 0 & 10 & 0:15:08 \\
\hline IK & $\check{Z}$ & $63 ; 02$ & anomička & ne & ne & 30 & 24 & 54 & ne & 6 & 4 & 4 & 1 & 0 & 9 & 0:09:58 \\
\hline
\end{tabular}

Tablica 6. Podaci o ispitanicima iz kontrolne skupine i njihovi rezultati ostvareni na zadacima auditivnog razumijevanja te na zadacima za percepciju i produkciju ritma

\begin{tabular}{|c|c|c|c|c|c|c|c|c|c|c|c|c|c|}
\hline \multirow[b]{3}{*}{ 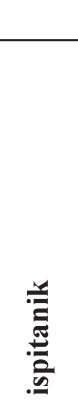 } & \multicolumn{13}{|c|}{ KONTROLNA SKUPINA ISPITANIKA } \\
\hline & \multirow[b]{2}{*}{ के } & \multirow[b]{2}{*}{ 웅 } & \multirow[b]{2}{*}{ 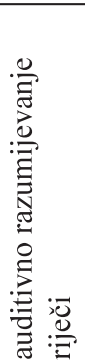 } & \multirow[b]{2}{*}{ 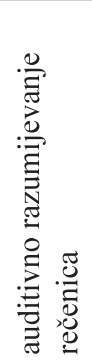 } & \multirow[b]{2}{*}{ 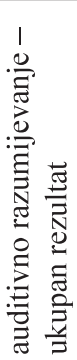 } & \multirow[b]{2}{*}{ 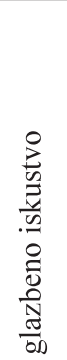 } & \multirow[b]{2}{*}{ 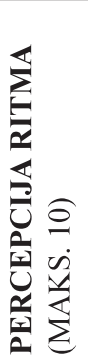 } & \multicolumn{5}{|c|}{ PRODUKCIJA RITMA } & \multirow[b]{2}{*}{ 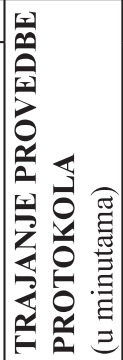 } \\
\hline & & & & & & & & 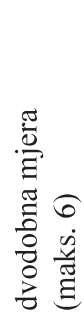 & 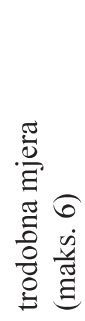 & 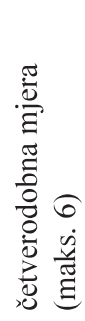 & 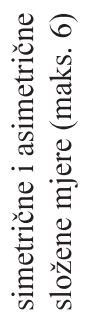 & 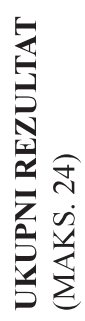 & \\
\hline MP & Ž & $36 ; 09$ & 30 & 27 & 57 & ne & 10 & 5 & 4 & 4 & 2 & 15 & $0: 06: 56$ \\
\hline MM & $\mathrm{M}$ & $67 ; 06$ & 30 & 28 & 58 & ne & 8 & 2 & 4 & 3 & 1 & 10 & 0:07:27 \\
\hline LA & $\mathrm{M}$ & $32 ; 04$ & 30 & 30 & 60 & $\mathrm{da}$ & 10 & 6 & 6 & 6 & 6 & 24 & 0:06:45 \\
\hline NS & $\mathrm{M}$ & $31 ; 03$ & 30 & 28 & 58 & ne & 9 & 6 & 5 & 6 & 4 & 21 & $0: 07: 35$ \\
\hline SH & $\mathrm{M}$ & $48 ; 11$ & 30 & 28 & 58 & $\mathrm{da}$ & 10 & 5 & 4 & 4 & 4 & 17 & $0: 06: 27$ \\
\hline RČ & M & $48 ; 08$ & 30 & 30 & 60 & $\mathrm{da}$ & 10 & 6 & 6 & 5 & 4 & 21 & 0:06:33 \\
\hline IL & Ž & $30 ; 04$ & 30 & 30 & 60 & ne & 10 & 5 & 4 & 4 & 4 & 17 & 0:06:40 \\
\hline DV & $\mathrm{M}$ & $24 ; 01$ & 30 & 28 & 58 & $\mathrm{da}$ & 10 & 6 & 5 & 6 & 5 & 22 & 0:06:55 \\
\hline ID & $\mathrm{M}$ & $56 ; 09$ & 30 & 30 & 60 & ne & 10 & 5 & 2 & 4 & 0 & 11 & $0: 10: 57$ \\
\hline IV & Ž & $63 ; 05$ & 30 & 28 & 58 & ne & 9 & 4 & 3 & 4 & 4 & 15 & 0:06:26 \\
\hline
\end{tabular}

(Brendel i Ziegler, 2008; Mauszycki i Wambaugh, 2008; Wambaugh i Martinez, 2000; prema Zipse i sur., 2014). Valja istaknuti kako uparivanje govora i ritamskih aktivnosti može biti korisno u organizaciji motoričkih govornih aktivnosti ako je sposobnost produkcije tj. otkucavanja ritma očuvana bolje od govorne produkcije (Hough, 2010; prema Zipse i sur., 2014). Prema tome ukoliko je sposobnost produkcije ritma, a samim time i percepcije ritma (jer je očuvana percepcija preduvjet ispravne produk- 
Tablica 7. Korelacije između postignuća na zadacima auditivnog razumijevanja i percepcije i produkcije ritma kod obiju skupina ispitanika

\begin{tabular}{|c|c|c|c|c|}
\hline & VARIJABLE & & perc_rit_ukup_10_posto & prod_rit_ukup_24_posto \\
\hline \multirow{6}{*}{$\begin{array}{l}\text { OSOBE S } \\
\text { AFAZIJOM }\end{array}$} & \multirow[t]{2}{*}{ aud_raz_riječi_posto } & $\mathbf{r}_{\mathrm{s}}$ & 0,606 & 0,555 \\
\hline & & $\mathbf{p}$ & 0,064 & 0,096 \\
\hline & \multirow[t]{2}{*}{ aud_raz_reč_posto } & $\mathbf{r}_{\mathrm{s}}$ & 0,320 & 0,518 \\
\hline & & $\mathbf{p}$ & 0,368 & 0,125 \\
\hline & \multirow[t]{2}{*}{ aud_raz_ukup_posto } & $\mathbf{r}_{\mathrm{s}}$ & 0,542 & 0,547 \\
\hline & & $\mathbf{p}$ & 0,106 & 0,102 \\
\hline \multirow{6}{*}{$\begin{array}{l}\text { KONTROLNA } \\
\text { SKUPINA }\end{array}$} & \multirow[t]{2}{*}{ aud_raz_riječi_posto } & $\mathbf{r}_{\mathrm{s}}$ & - & - \\
\hline & & $\mathbf{p}$ & - & - \\
\hline & \multirow[t]{2}{*}{ aud_raz_reč_posto } & $\mathbf{r}_{\mathrm{s}}$ & 0,295 & 0,233 \\
\hline & & $\mathbf{p}$ & 0,409 & 0,518 \\
\hline & \multirow[t]{2}{*}{ aud_raz_ukup_posto } & $\mathbf{r}_{\mathrm{s}}$ & 0,240 & 0,315 \\
\hline & & $\mathbf{p}$ & 0,505 & 0,376 \\
\hline
\end{tabular}

$\mathbf{r}_{\mathbf{s}}=$ Spearmanov koeficijent korelacije; $\mathbf{p}>0,05$

cije) narušena, osoba s afazijom neće imati koristi od tretmana temeljenog na korištenju ritma (Zipse i sur., 2014). Uzimajući u obzir dobivene rezultate, odbacuje se Treća hipoteza (H3) i zaključuje se da ne postoji povezanost između postignuća na zadacima auditivnog razumijevanja riječi i rečenica i sposobnosti percepcije i produkcije ritma kod obiju skupina ispitanika.

\section{Analiza odgovora}

Iz Tablice 8. vidljivo je da su ispitanici najuspješnije rješavali zadatke za percepciju ritma u kojima su prezentirana dva istovjetna ritamska primjera, dok su najviše teškoća imali s razlikovanjem primjera među kojima su razlike minimalne (na primjer različite ritamske figure $\mathrm{s}$ istim brojem otkucaja). Dobiveni rezultati nisu neočekivani budući da su brojni ispitanici naveli da je njihova glavna strategija za upamćivanje ritamskih primjera koje su trebali usporediti bilo brojanje otkucaja. U skupini zadataka za produkciju ritma ispitanici su najuspješnije ponavljali jednostavnije ritamske figure s manjim brojem otkucaja. Najviše teškoća imali su pri ponavljanju složenijih ritamskih figura te ritamskih figura s većim brojem otkucaja kraćeg trajanja (na primjer uzastopnih šesnaestinki ili triola). Imajući na umu dodatno opterećenje za radno pamćenje i motoričku izvedbu koje za osobe s neurološkim oštećenjem predstavlja izvođenje složenijih ritamskih figura s većim brojem otkucaja dobiveni rezultati su očekivani.
Tablica 8. Primjeri ispitnih čestica Protokola koje su ispitanici rješavali s najvećim is najmanjim uspjehom

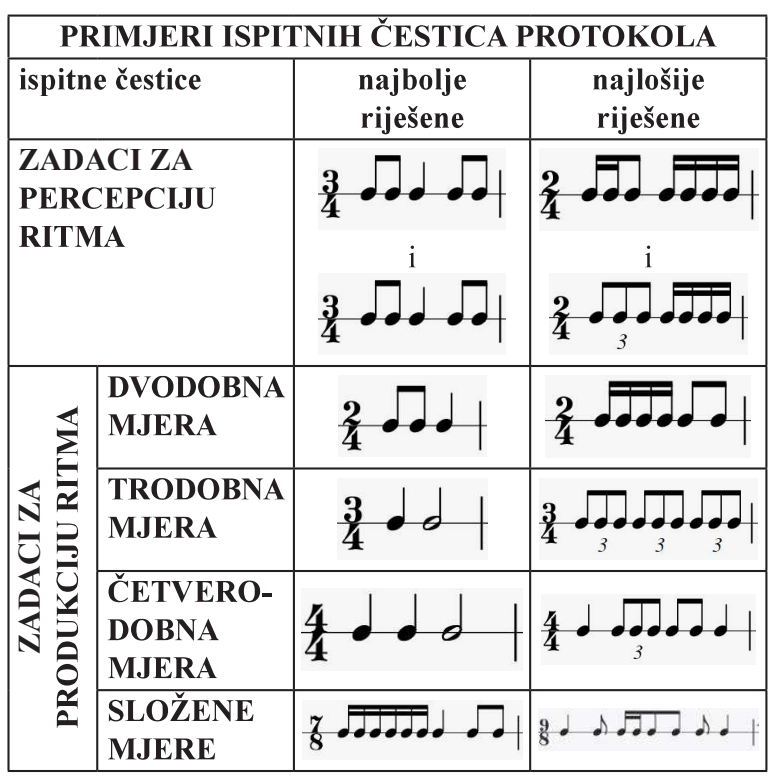

Kvalitativnom analizom dobivenih rezultata na individualnoj razini uočeno je da se odgovori ispitanika JV razlikuju od odgovora drugih ispitanika iz skupine osoba s afazijom. Dotični ispitanik ima dijagnozu globalne afazije čija su temeljna obilježja teškoće jezičnog razumijevanja i jezične proizvodnje. Karakterističan simptom globalne afazije jest prisustvo perseveracija - uzastopnog ponavljanja određenih riječi u govoru. Zabilježeno je da ispitanik JV uzastopno ponavlja riječ "to". Ispitanik JV je na većinu ispitnih čestica iz skupine zadataka za produkciju ritma odgovarao otkuca- 
vanjem identičnog ritamskog obrasca, preciznije otkucavanjem tri uzastopne četvrtinke. Zbog toga je moguće izjaviti da su kod spomenutog ispitanika prisutne perseveracije u produkciji ritma. U ovom je istraživanju sudjelovao samo jedan ispitanik s dijagnozom globalne afazije, a u literaturi nije pronađen opis slučaja sličnog ovome pa nije moguće donijeti generalizirani zaključak i potvrditi pretpostavku da su kod osoba s globalnom afazijom uz perseveracije u govoru prisutne i perseveracije u produkciji ritma. Stoga ovaj pronalazak otvara novo istraživačko pitanje: jesu li perseveracije u produkciji ritma obilježje globalne afazije kao što su perseveracije u govoru?

\section{ZAKLJUČAK}

Neupitno je da je ritam ključan za razumljivost govora te da je govorni ritam kod osoba s afazijom netečnog tipa narušen zbog čega je razumljivost njihova govora smanjena. Dosad je uloga ritma u rehabilitaciji govora bila zapostavljena, pa su tako $\mathrm{i}$ istraživanja percepcije $\mathrm{i}$ produkcije ritma kod ove skupine ispitanika malobrojna, naročito u Republici Hrvatskoj. Budući su neki logopedski tretmani poput terapije melodijskom intonacijom ili govorno-glazbene terapije za afaziju temeljeni na korištenju ritma, potrebno je ispitati i opisati teškoće obrade ritma kod osoba s afazijom jer bi upravo očuvanost sposobnosti percepcije i produkcije ritma trebala biti jedan od kriterija za uključivanje osoba s afazijom u navedene terapijske programe. Novorazvijeni Protokol za ispitivanje percepcije $i$ produkcije ritma kod osoba s afazijom korišten u ovom istraživanju odgovor je na navedeni problem.

Rezultati ispitivanja percepcije i produkcije ritma kod osoba s afazijom netečnog tipa očekivano potvrđuju da su osobe $s$ afazijom uspješnije na zadacima za percepciju nego na zadacima za produkciju ritma te da skupina prosječnih govornika postiže bolje rezultate na zadacima za ispitivanje percepcije i produkcije ritma od osoba s afazijom. Pretpostavka da postoji povezanost između sposobnosti percepcije i produkcije ritma te postignuća na zadacima auditivnog razumijevanja kod osoba s afazijom i kod prosječnih govornika ovim istraživanjem nije potvrđena. Budući da se sposobnost obrade ritma više dovodi u vezu s jezičnom produkcijom, a naročito s motoričkom izvedbom govora, i ovaj je pronalazak očekivan.

Glavna su ograničenja opisanog istraživanja malen broj ispitanika s afazijom te heterogenost uzorka. Iako su navedeni problemi uobičajeni u istraživanjima iz područja afaziologije, vrijedi istaknuti da su i inozemna istraživanja na ovu temu rijetka, a uzorci nerijetko još i manji.

Ovu je temu potrebno i dalje istraživati uz nastojanje da u budućim istraživanjima sudjeluje čim veći broj ispitanika s afazijom te da se uključe stručnjaci različitih profila jer ispitivanje percepcije i produkcije glazbenog ritma kod osoba s afazijom nema samo kliničke implikacije već je važno i za otkrivanje novih činjenica o organizaciji i funkcioniranju mozga. 
Hrvatska revija za rehabilitacijska istraživanja 2020, Vol 56, br. 1, str. 19-32

\section{LITERATURA}

Albert, M., Sparks, R. W., Helm, N. A. (1973). Melodic Intonation Therapy for Aphasia. Archives of Neurology, 29, 130-131.

Bruijn, M. de, Zielman, T., Hurkmans, J. (2005). Speech-music therapy for aphasia, SMTA. Friesland: Revalidatie.

Curtis, S., Nicholas, M. L., Pittmann, R., Zipse, L. (2019). Tap your hand if you feel the beat: differential effects of tapping in melodic intonation therapy. Aphasiology, https://doi.org/10.1080/02687038.2019.1621983.

Davis, G. A. (2007). Aphasiology: Disorders and Clinical Practice. Boston: Pearson.

Ding, N., Patel, A. D., Chen, L., Butler, H., Luo, C., Poeppel, D. (2017). Temporal Modulations in Speech and Music. Neuroscience \& Behavioural Reviews, http://dx.doi.org/10.1016/j.neubiorev.2017.02.011.

Duffy, E. (2014). A Dual Task Paradigm: The cerebral laterality of pitch and rhythm and implications for aphasia therapy. (Diplomski rad). Department of Speech, Language and Hearing Sciences, University of Colorado at Boulder.

Fujii, S. i Wan, C. Y. (2014). The role of rhythm in speech and language rehabilitation: the SEP hypothesis. Frontiers in Human Neuroscience, 8, 1-15.

Grahn, J. (2009). The role of the basal ganglia in beat perception: neuroimaging and neuropsychological investigations. Annals of the New York Academy of Sciences, 1169, 35-45.

Hegde, M. N. (2006). A Coursebook on Aphasia and Other Neurogenic Language Disorders, Third Edition. New York: Thomas Delmar Learning.

Horváth, R.A., Schwarcz, A., Aradi, M., Auer, T., Feher, N., Kovács, N., Tényi, T., Szalay, C., Perlaki, G., Orsi, G., Komoly, S., Dóczi, T., Woermann, F.G., Gyimesi, Cs., Janszky, J. (2011). Lateralisation of non-metric rhythm. Laterality: Asymmetries of Body, Brain and Cognition, 16 (5), 620-635.

Hrvatska enciklopedija. Ritam. Preuzeto 21.11.2018. s http://www.enciklopedija.hr/natuknica.aspx?id=52994.

Huber, W., Poeck, K., Willmes, K. (1983). Aachen Aphasia Test. Hrvatska preliminarna verzija razvijena od strane Prizl Jakovac, T. (u pripremi). Zagreb: Odsjek za logopediju.

Jonkers, R., Terband, H., Maassen, B. (2014). Diagnosis and Therapy in Adult-Acquired Dysarthria and Apraxia of Speech in Dutch. U: Miller, N. i Lowit, A. (ur.): Motor Speech Disorders: A Cross-Language Perspective. (str. 156-167). Bristol: Multilingual Matters.

Kershenbaum, A., Nicholas, M.L., Hunsaker, E., Zipse, L. (2017). Speak along without the song: what promotes fluency in people with aphasia?. Aphasiology, https://doi.org/10.1080/02687038.2017.1413487.

Kim, M. i Tomaino, C. M. (2008). Protocol Evaluation for Effective Music Therapy for Persons with Nonfluent Aphasia. Topics in Stroke Rehabilitation, 15 (6), 555-569.

Papathanasiou, I., Coppens, P., Potagas, C. (2013). Aphasia and Related Neurogenic Communication Disorders. Burlington: Jones \& Bartlett Learning.

Patel, A. D. (2003). Rhythm in Language and Music: Parallels and Differences. Annals of the New York Academy of Sciences, 999, 140-143.

Patel, A. D., Iversen, J. R., Rosenberg, J. C. (2006). Comparing the rhythm and melody of speech and music: The case of British English and French. The Journal of the Acoustical Society of America, 5 (119), 3034-3047.

Patel, A. D. (2012). Language, music, and the brain: a resource-sharing framework. U: Rebuschat, P., Rohrmeier, M., Hawkins, J., Cross, I. (ur.): Language and Music as Cognitive Systems (str. 204-223). Oxford: Oxford University Press.

Patel, A.D. i Iversen, J.R. (2014). The evolutionary neuroscience of musical beat perception: Action Simulation for Auditory Prediction (ASAP) hypothesis. Frontiers in Systems Neuroscience, https://doi.org/10.3389/ fnsys.2014.00057. 
Prizl Jakovac, T. (2002). Glazbene sposobnosti osoba s afazijom. U: Prstačić, M. (ur.): Zbornik radova 1. međunarodnog simpozija Umjetnost i znanost u razvoju životnog potencijala (str. 281-284). Zagreb: Hrvatska udruga za psihosocijelnu onkologiju i Edukacijsko-rehabilitacijski fakultet Sveučilišta u Zagrebu.

Raglio, A., Oasi, O., Gianotti, M., Rossi, A., Goulene, K., Stramba-Badiale, M. (2016). Improvement of spontaneous language in stroke patients with chronic aphasia treated with music therapy: a randomized controlled trial. International Journal of Neuroscience, 126 (3), 235-242.

Škarić, I. (1992). Fonetika hrvatskoga književnog jezika. U: Povijesni pregled, glasovi i oblici hrvatskoga književnog jezika: Nacrt za gramatiku. (str. 61-379). Zagreb: HAZU - Globus.

Tomaino, C.M. (2012). Effective music therapy techniques in the treatment of nonfluent aphasia. Annals of the New York Academy of Sciences, 1252, 312-317.

Tomašić, Đ. (2003). Osnove glazbene teorije. Zagreb: ERUDIT.

Zipse, L., Worek, A., Guarino, A. J., Shattuck-Hufnagel, S. (2014). Tapped Out: Do People With Aphasia Have Rhythm Processing Deficits?. Journal of Speech, Language, and Hearing Research, 57, 2234-2245.

Zumbansen, A. i Tremblay, P. (2018). Music-based interventions for aphasia could act through a motor-speech mechanism: a systematic review and case-control analysis of published individual participant data, Aphasiology, https://doi.org/10.1080/02687038.2018.1506089.

\section{ASSESSMENT OF MUSICAL RHYTHM PERCEPTION AND PRODUCTION IN PEOPLE WITH APHASIA}

\footnotetext{
Abstract: Exploring the relationship between rhythm and speech is necessary for understanding and creating speech therapies for people with neurogenic communication, language and speech disorders, especially people with nonfluent aphasia. The aim of the present study, involving 10 subjects with aphasia and 10 average speakers, was to examine whether there are difficulties in musical rhythm perception and production in people with aphasia, to find out whether there are differences between musical rhythm perception and production within the same group of subjects and to determine whether there is a correlation between achievement on tasks of auditory comprehension and rhythm perception and production. "The Protocol for Assessment of Rhythm Perception and Production in People with Aphasia", which consists of musical rhythm perception and production tasks, was created for the purpose of this study. A statistically significant difference was found between the achievement of people with aphasia and the control group on the applied tasks of rhythm perception and production. A correlation was not found between rhythm perception and production and achievement on tasks of auditory comprehension, among either people with aphasia or the control group. Analysis of the subjects' answers revealed the features of the rhythmic patterns that make it easy or difficult to perceive and reproduce a rhythm.
}

Keywords: aphasia, rhythm, perception, production, music therapy 